\title{
The Differences Between Pre-Service Chemistry, Fine Art, and Primary Education Teachers Regarding Interest and Knowledge About Fine Art Materials
}

Robert Potočnik ${ }^{\star 1}$ AND IzToK Devetak ${ }^{2}$

$\approx \quad$ The primary purpose of this paper is to identify the level of interest and knowledge about fine art materials (in selected works of art) that can influence pre-service primary school, chemistry, and fine art teachers' implementation of this content into their teaching. This knowledge can help them be aware of how a specific fine art material can be used in fine art classes. Fine art materials can also be applied in different manners by chemistry teachers and primary school teachers (science lessons) to explain the specific chemical characteristics of these substances. Altogether, 118 pre-service teachers from the Faculty of Education, University of Ljubljana participated in the study. The data were collected using three instruments: information about participants (IP), fine art materials achievement test (FAMAT), and individual interest questionnaire (IIQ), which comprise items for self-concept. It can be concluded that pre-service teachers' average score $(49.6 \%)$ on FAMAT is quite low. The results also showed that pre-service fine art teachers achieved better results than the other two groups did. Similar results were also obtained regarding participants' interest and self-concept in learning about fine art materials. It can be concluded that more emphasis should be placed on developing the understanding of chemical and fine art concepts due to the fact that fine art and chemistry can be interdisciplinarily connected in education, according to contemporary curricular guidelines.

Keywords: fine art materials, interest, pre-service teachers' knowledge, science education

$1 \quad{ }^{\star}$ Corresponding Author. University of Ljubljana, Faculty of Education, Slovenia; Robert. potocnik@pef.uni-lj.si.

2 University of Ljubljana, Faculty of Education, Slovenia. 


\section{Razlike v zanimanju in znanju o materialih likovnih del med prihodnjimi učitelji kemije, razrednega pouka in likovne pedagogike}

\section{Robert Potočnik In Iztok Devetak}

$\propto$ Glavni namen tega prispevka je določiti raven zanimanja in znanja o materialih v izbranih likovnih delih, ki lahko vplivajo na poučevanje na razredni stopnji ter poučevanje kemije in likovne umetnosti. Znanje o likovnih materialih lahko prihodnjim učiteljem likovne pedagogike in razrednega pouka pomaga pri uporabi v okviru likovne dejavnosti. S pomočjo likovnih materialov lahko prihodnji učitelji kemije in razrednega pouka razložijo specifične kemijske lastnosti teh snovi. V raziskavi je sodelovalo 118 prihodnjih učiteljev Pedagoške fakultete Univerze v Ljubljani. Podatki so bili zbrani z uporabo treh instrumentov: informacije o udeležencih, testa znanja o likovnih materialih in vprašalnika o zanimanju o likovnih materialih, ki je vključeval tudi elemente samopodobe. Povprečno znanje študentov o likovnih materialih je precej nizko (49,6 \%). Rezultati so tudi pokazali, da prihodnji učitelji likovne pedagogike izkazujejo več znanja v primerjavi s prihodnjimi učitelji razrednega pouka in kemije. Podobni rezultati so bili pridobljeni tudi glede posameznikovega interesa in samopodobe za učenje o likovnih materialih. Raziskava izkazuje, da je treba bolj poudariti razvijanje razumevanja kemijskih in likovnih pojmov, saj so lahko v izobraževanju vsebine likovne umetnosti in kemije interdisciplinarno povezane, kar je skladno s smernicami sodobnih učnih načrtov.

Ključne besede: likovni materiali, zanimanje, znanje študentov, naravoslovno izobraževanje 


\section{Introduction}

Fine art and chemistry can be interdisciplinarily integrated into education from the primary to secondary and university levels. The primary purpose of this paper is to identify the level of knowledge about fine art material that can influence primary school, chemistry, and fine art teachers' implementation of this context into their teaching. It is essential to emphasise that knowledge of the chemistry of fine art materials can be beneficial for fine art teachers. This knowledge can help them be aware of possibilities and limitations that a specific fine art material can be used to define the techniques and application of these materials in fine art classes. Chemistry teachers can benefit from fine art materials when explaining the chemical characteristics of these substances.

The chemistry education community has recognised that the examination of artwork is a valuable tool for teaching science to students at all stages of education (Uffelman, 2007). Since the late 1970s, different reports have suggested how to integrate fine art into chemistry classes in ways that represent the cognitive features of chemistry contents through various fine art materials, fine art techniques, and other features of artworks (Denio, 1979; Newman, 1972; Stamovlasis, 2003).

One of the aims of the general science and chemistry curriculum is to make science and chemistry more relevant to students, including by relating art to chemistry in interdisciplinary, individualised, and life-oriented approaches to learning the content of these subjects (Kafetzopoulos, Spyrellis, \& Lymperopoulou-Karaliota, 2006). Gaquere-Parker and Perker (2012) suggested that students from all backgrounds benefit from working with real-life applications of chemistry and by keeping the students engaged with cross-disciplinary examples (such as fine art products). Using simple art concepts can assist non-science university students in better appreciating scientific facts related to chemistry (Hemraj-Benny \& Beckford, 2014).

For implementation in school environments, practices dealing with fine art materials and techniques can be found, for example making paint (Potočnik, 2017; Solomon Rutkowsky, Mahon, \& Halpern, 2011) and exploring ancient and modern pigments (Orna, 2001), dyes and dying process (Alves, Manhita, Barrocas Diasb, \& Ferreira, 2014; Epp, 1995), glass, pottery, and ceramics (Denio, 2001; Kolb \& Kolb, 200o). Furthermore, in close observation of art objects, students can be introduced to a variety of modern analytical tools and tests designed to assess the composition, age, and condition of art objects. Students learn to perform elemental analyses with a hand-held X-ray device, fluorescence (XRF) device, to collect infrared (IR) spectroscopic data on dyes 
and binders, to use gas chromatography and mass spectrometry (GC-MS) to analyse paint-binding media, and to use florescence microscopy for close observation of paint chip cross-sections (Wells \& Haaf, 2013).

Some research (Burton, Horowitz, \& Abeles, 1999; Danipog \& Ferido, 2011) in the last two decades has shown that students exposed to art-based chemistry activities have significantly higher mean scores in chemistry achievement tests (e.g., they easily made connections between new and old information, they related the familiar with the unfamiliar information, and integrated the new intellectual challenge into the existing mental structures) than the students exposed to non-art-based activities did.

As mentioned above, fine art material can be used for stimulating students' individual interests and self-concepts about science in general (e.g., students beliefs about their academic performance), and specifically in chemistry. According to Schraw, Flowerday, and Lehman (2001), interest stimulates learning, and promoting interest in the classroom increases students' intrinsic motivation to learn (Belova \& Eilks, 2014; Pressley, El-Dinary, Marks, Brown, \& Stein, 1992; Slapničar, Devetak, Glažar, \& Pavlin, 2017). Interest is one of the components of the intrinsic motivation for learning and could be described as 'psychological arousal including focused attention, increased cognition, persistence and emotional involvement' (Hidi, 200o, p. 311). Research shows that there is a stable distinction between two types of interest: individual (personal) and situational interest (in the context of the specific situation). Personal interest is oriented to the areas that are characterised by the individuals' complete dedication to the task or learning problem (Renninger, 2000). Among the pre-service primary school teachers in Slovenia, interest in chemistry is low (Juriševič, Devetak, Razdevšek-Pučko, \& Glažar, 2008).

The other important aspect of someone's awareness of their learning problems is their self-concept. As Landsman (1962, p. 286) defined, 'self-concept is an organised group of feelings and attitudes which an individual is concerning himself' while learning a specific topic. McCarthy and Schmeck (1988) also described self-concept as an important cognitive structure organising an individual's experience. One's self-concept can, for that matter, steer the process of learning with stimulating or obstructing the cognition processes.

Some research shows that in general students' interest in fine art is higher than in other subjects, so it can be deduced that an interdisciplinary approach could be useful for teaching science and chemistry (Dhanpal, Kanapathy, \& Mastan, 2014). Artworks could be an adequate tool for achieving stimulating situations among students for learning chemistry, for example: finding hidden chemistry in Egyptian artefacts (e.g., arsenic, copper, lead substances in 
pigments and the degradation of its colour over time) (Gimenez, 2015), exploring different material components of artefacts in museum collections (Brown, Losoff, \& Hollis, 2014), or frescos found in Pompeii that contain mercury in the vermilion pigments (Gaquere-Parker \& Perker, 2012). Some authors report that younger students (in primary school) and their parents were highly positive about the activities (for example, making a copper-based pigment and painting with it); many parents requested ideas on how to perform similar experiments at home (Gaquere-Parker, Allie Doles, \& Parker, 2016).

When assessing students' level of understanding of fine art material concepts, different diagnostic instruments can be used. One option is the application of the multi-tier diagnostic instruments that come in various forms and can be used to identify students' misconceptions, as suggested by Treagust (1988). The two-tier test is quite popular and has been used in numerous research studies in science education. This form cannot distinguish correct responses on the basis of whether these are due to guesswork or content mastery. These limitations can be addressed significantly with the use of three-tier or four-tier diagnostic questions. In these instruments, a confidence rating (typically on a scale from just guessing (1) to absolutely confident (6)) is added. If the confidence tier is appended to both tiers separately, the instrument is four-tiered, and where a mean rating is required in respect of answer and reason tiers, it becomes a three-tier instrument. Because the answer and reason tiers may have different difficulty levels, it is reasonable to assume that students would have different levels of confidence for both tiers (Caleon \& Subramaniam, 2010; Gurel, Eryilmaz, \& McDermott, 2015). For the purpose of this paper, only students' responses to the answer and reason tiers were used.

Overall, it can be summarised according to the literature review that cross-curricular integration of the content could be a useful tool to develop adequate understanding of the chemical and fine art concepts; therefore, the knowledge about fine art materials that different teachers (e.g., fine art, chemistry, and primary school) have is one of the most critical factors of context inclusion.

\section{Research problem and research questions}

Some attempts have been made to popularise the correlations between chemistry and fine arts so that chemistry teachers would be aware of the possibilities of using fine art in chemistry classrooms (Vrtačnik, 2004) in Slovenia. However, the contents of learning about some specific chemistry concepts through artworks in the primary, lower, and upper secondary schools had not 
been emphasised previously, and has not come to implementation as part of the science, chemistry, and/or fine art subjects. Consequently, the main purpose of this paper is to identify the level of knowledge about fine art material that can influence primary school, chemistry, and fine art pre-service teachers' implementation of this context into their teaching. This knowledge can help pre-service fine art teachers be aware of the possibilities and limitations of a specific fine art material when using it to define techniques and the application of these materials in fine art classes. Fine art materials can be used by preservice chemistry teachers and pre-service primary school teachers to explain the chemical characteristics of these substances. This implementation of fine art materials in science lessons and vice-versa can provide an interdisciplinary approach to education. It is, therefore, up to the pre-service teachers to use their own competences to include (or not) the interdisciplinary contents related to fine art materials, according to the curriculum.

To present the context of the research, the Slovenian educational system should be introduced. The primary school teacher (graduates from the Faculty of Education) teaches the subjects Learning about the Environment, Science and Technology, and Fine Art between the $1^{\text {st }}$ and $5^{\text {th }}$ grades (6-10-year-old students); the chemistry teacher teaches the subject Chemistry in the $8^{\text {th }}$ and $9^{\text {th }}$ grades (13- and 14-year-old students); the fine art teacher usually teaches fine art from the $6^{\text {th }}$ to $9^{\text {th }}$ grades (11- and 14-year-old students). The Chemistry teacher and Fine Art teacher (graduates from the Faculty of Education) can also teach at the upper secondary level if the subject is not part of the Matura exam (national external exam at the end of upper secondary school). According to the research problem, five research questions were formed:

RQ1: How significantly do pre-service fine art teachers differ in the fine art materials achievement test (FAMAT) scores from pre-service chemistry or primary education teachers?

RQ2: How significantly do pre-service teachers who create fine arts products in their free time (drawings, painting, sculpting, etc.) differ in FAMAT scores than those who do not?

RQ3: How significantly do pre-service chemistry, fine art, and primary school teachers differ in levels of individual interest and self-concept for learning about fine art materials?

RQ4: How significantly do pre-service teachers who expressed higher individual interest in art material differ in achievement scores on FAMAT?

RQ5: How significantly do pre-service teachers who expressed higher selfconcept for art material differ in achievement scores on FAMAT? 


\section{Method}

\section{Sample}

Altogether, 118 pre-service teachers from the Faculty of Education, University of Ljubljana participated in the study; 21 (17.8\%) of them were fine art pre-service teachers, 25 (21.2\%) pre-service chemistry teachers, and 72 (61.0\%) were pre-service primary school teachers. There were only 14 males (11.9\%), and the average age was 22.8 years ( $S D=1.2$ years). All students were in the fourth year of undergraduate study. To illuminate the participants' fine art and chemistry backgrounds, we emphasise that in the Slovenian primary and lower secondary school system, chemistry, and fine art are obligatory subjects. However, in the upper secondary school system, some programmes do not include the subjects Chemistry or Fine Art. In our research, four (3.4\%) participants had not taken upper secondary chemistry, and two (1.7\%) had not taken fine art. At the Faculty of Education, pre-service chemistry teachers cannot participate in any fine art courses, and pre-service fine art teachers cannot participate in any chemistry courses. Pre-service primary school teachers participate in the science (chemistry topics) course during a 15-week period (30 hours of lectures; 25 hours of lab work and 5 hours of field work) in the first year of undergraduate study and fine art course during a 15-week period ( 45 hours of lectures and 30 hours of practical work) in the third year of undergraduate study.

\section{Instruments}

The data was collected using three instruments: the information about participants (IP), the fine art materials achievement test (FAMAT), and the individual interest questionnaire (IIQ), which comprise items for self-concept.

\section{The information about participants (IP)}

The IP questionnaire comprises general information about the participants (e.g., gender, age, study programme, creating fine art products in their free time), a five-point scale about interest in chemistry and fine art in primary, lower secondary and upper secondary schools, and a matching item about colour concepts such as the difference between the concepts of colour, colouring substance (paint and pigment) to determine pre-service students' basic knowledge of these concepts.

\section{The fine art materials achievement test (FAMAT)}

The FAMAT was constructed as a diagnostic test using the methodological framework to identify students' misconceptions, as suggested by 
Treagust (1988). It includes four-tier multiple-choice items. The FAMAT comprises six tasks (each task shows a different visual representation of a painting; for example; on stone, wood, wall, and other); each task has two different parts. In the first part, participants had to define the type of painting support and in the second part the materials of painting layers. Each part comprises four different questions; see Figure 1 for an example of such a task. The construct validity of the instrument was confirmed by three independent experts in chemical education, fine art education and, cultural heritage conservation/ restoration. For the purpose of this paper, only global achievement means of FAMAT were used. 
A detail of a fresco painting is displayed (Sandro Botticelli and assistants, Sistine Chapel, 1481-1482).

Answer the following questions based on your experience in the context of fine art materials.

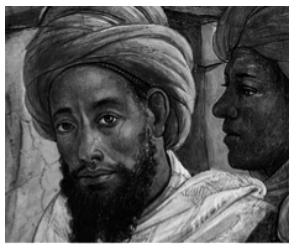

Image used from Wikipedia.

1.1 What is the support of the painting?
A Lime plaster.
B Stone.
C Wood.
D Metal.

1.2 How sure are you about the correct answer under 1.1?

$\begin{array}{cccccc}1 & 2 & 3 & 4 & 5 & 6 \\ \text { Just } & \text { Very } & \text { Unconfident } & \text { Confident } & \begin{array}{c}\text { Very } \\ \text { confident }\end{array} & \begin{array}{c}\text { Absolutely } \\ \text { confident }\end{array}\end{array}$

1.3 State the reason for the specific answer under 1.1?

A The stone surface could be seen on the fresco painting.

B Smooth texture, which is typical for the wall surface, could be seen on the fresco painting.

C Patine could be seen, on the fresco painting which is formed on the surface of the metal when it is exposed to the air.

D The visible structure and colour of the wood, formed after the treatment could be seen on the fresco painting.

1.4 How sure are you about the correct answer under 1.3?

$\begin{array}{cccccc}1 & 2 & 3 & 4 & 5 & 6 \\ \text { Just } & \text { Very } & \text { Unconfident } & \text { Confident } & \begin{array}{c}\text { Very } \\ \text { confident }\end{array} & \begin{array}{c}\text { Absolutely } \\ \text { confident }\end{array}\end{array}$

1.5 Which materials were used for painting (painting layers)?

A Pigments like chromium and cobalt oxides, compounds of lead and antimony and calcium hydroxide (slaked lime) as a binder.

B Pigments like iron oxides, lead carbonate and lead hydroxide, copper carbonate, iron hexacyanoferrate and liquid fat-oil as a binder.

C Pigments like chromium and cobalt oxides, lead and antimony compounds, iron oxides, lead carbonate and lead hydroxide, copper carbonate, iron hexacyanoferrate and egg yolk as a binder.

D Pigments like iron oxides, carbon from burning wood and bones, calcium carbonate-calcite and saliva or fat as binder.

1.6 How sure are you about the correct answer under 1.5 ?

$\begin{array}{cccccc}1 & 2 & 3 & 4 & 5 & 6 \\ \text { Just } & \text { Very } & \text { Unconfident } & \text { Confident } & \begin{array}{c}\text { Very } \\ \text { confident }\end{array} & \begin{array}{c}\text { Absolutely } \\ \text { confident }\end{array}\end{array}$

1.7 State the reason for the specific answer under 1.5?

A We can find the typical texture of wall surface with materials that could be painted on-fresh lime plaster.

B We can find the typical texture of applied oil colours of different thicknesses, cracks (craquelure) and gentle transitions between shades of colours.

C We can find the typical texture of thinner application of the painted layer on the wooden support with the hatching pattern (tratteggio) and sharp transitions between shades of colours.

D We can find the typical texture of thin layers of various materials, without any preparation of painting support.

1.8 How sure are you about the correct answer under 1.7?

\begin{tabular}{|c|c|c|c|c|c|}
\hline $\begin{array}{c}1 \\
\text { Just } \\
\text { guessing }\end{array}$ & $\begin{array}{c}2 \\
\text { Very } \\
\text { unconfident }\end{array}$ & $\begin{array}{c}3 \\
\text { Unconfident }\end{array}$ & $\begin{array}{c}4 \\
\text { Confident }\end{array}$ & $\begin{array}{c}5 \\
\text { Very } \\
\text { confident }\end{array}$ & $\begin{array}{c}6 \\
\text { Absolutely } \\
\text { confident }\end{array}$ \\
\hline
\end{tabular}

Figure 1. An example of the task comprising FAMAT; answer tier (1.1.; 1.5.), confidence tier for answer (1.2.; 1.6.), reason tier (1.3; 1.7); confidence tier for reason (1.4.; 1.8.); the correct answer and the correct reason are marked in bold and underlined. 


\section{The individual interest questionnaire (IIQ)}

The third instrument used in this research is the individual interest questionnaire (IIQ). It includes items about students' individual interest in fine art materials (e.g., 'I am interested in the works of fine art, so I'm often viewing them (in the galleries, churches, etc.; 'I want to deepen my knowledge problems related to the fine art materials.') and their self-concept about learning about fine art materials (e.g., 'The content dealing with the materials of the fine art products is not too difficult to understand.; ' When I create artwork with different materials (for example, painting, sculpturing, making posters...), I achieve good grades'). The response to each item is on a five-point Likert-type scale anchored at $1=$ strongly disagree, $2=$ disagree, $3=$ agree, $4=$ strongly agree, and 5 = cannot decide).

The internal consistency (Cronbach $\alpha$ ) of the individual interest scale in IIQ was .82. The average inter-item correlation was determined to indicate the self-concept scale in the IIQ level of consistency due to the small number of items in this scale. The average value is .53, showing optimal inter-item correlation for the self-concept scale. Three independent experts confirmed the validity of the instrument in chemistry, fine art education, and educational psychology. All instruments were designed specifically for this study.

\section{Research design}

The design of the research was non-experimental, cross-sectional, and descriptive. The research was conducted in May 2017. All instruments were applied anonymously in groups, and all the participants had the same conditions for completing the questionnaires and the FAMAT achievement test. The participants were informed that the data would be used for research purposes only, and the main objective of the study was explained. Participants spent on average 35 minutes to fulfil the questionnaires and solve the achievement test.

The acquired data were analysed using SPSS 22. Descriptive statistics (mean (M), standard deviations (SD)) were applied to reveal the knowledge, and interest characteristics of the participants. To determine the differences in mean scores regarding their undergraduate pre-service teacher education programme (fine art, chemistry, and primary school education), the paired-sample $\mathrm{t}$-test was used. Pearson's correlation coefficients for determining the correlation between colour concepts and results on FAMAT, individual interest, and self-concept about fine art material were calculated. In addition, the one-way between-groups analysis of variance (ANOVA) was conducted to explore the influence on knowledge, interest, self-concept of learning about fine art materials. If the test of homogeneity of variances was statistically significant when 
comparing the means of the groups of participants, the more robust test (Welch test) of equality of means was used. Statistical significance $(p \leq .05)$ was determined for all differences between means that were calculated.

\section{Results and discussion}

Due to the lack of literature at our disposal about the context of our research problem, the discussion part of our paper is limited. The results of the analysis are reported according to the research questions.

\section{Pre-service teachers' knowledge about fine art materials}

The first research question relates to the differences between pre-service teachers who study fine art education, chemistry education, or primary education in achievements on FAMAT scores. It is important to emphasise that achievements on FAMAT were quite low. Participants achieved 11.9 points out of 24.0 on average; this means that participants gathered only $49.6 \%$ of all points on the achievement test. If the analysis of the success on FAMAT is performed in more detail, regarding the pre-service educational programme, it can be summarised that the highest average success is identified in fine art teachers ( $68.8 \%$ of all points), followed by the primary school teachers (48.3\%) and the lowest level of fine art materials knowledge was expressed by pre-service chemistry teachers $(36.3 \%)$. This is expected, because pre-service chemistry teachers do not have a course in their undergraduate study in which these topics are covered. The ANOVA was conducted to explore the differences between three groups regarding their undergraduate pre-service teacher education programme (Group 1: chemistry, Group 2: fine art, Group 3: primary education). The differences are statistically significant $(F(2,115)=25.05, p \leq .000)$. The effect size, calculated using eta squared, was 0.303 ; this means that effect size is large, and $30.3 \%$ of the change in the FAMAT score can be accounted for by the pre-service education programme. Post hoc comparisons using Tukey HSD indicated that the mean score between Group $1(M=8.7 ; S D=3.4)$ was significantly different from Group $2(M=16.5 ; S D=3.8)$ and between Groups 1 and 3 $(M=11.6 ; S D=3.9)(p \leq .000)$. The different between Group 2 and Group 3 is also statistically significant $(\mathrm{p}=.003)$. The number and proportion of correct answers to the four questions in each of six tasks of the FAMAT by the three groups of pre-service teachers are presented in Table 1. 
Table 1

The success of pre-service teachers on FAMAT

\begin{tabular}{|c|c|c|c|c|c|c|}
\hline \multirow{2}{*}{$\begin{array}{l}\text { The content of the } \\
\text { specific item in the } \\
\text { FAMAT }\end{array}$} & \multicolumn{2}{|c|}{$\begin{array}{c}\text { Pre-service } \\
\text { chemistry teachers }\end{array}$} & \multicolumn{2}{|c|}{$\begin{array}{c}\text { Pre-service } \\
\text { fine art teachers }\end{array}$} & \multicolumn{2}{|c|}{$\begin{array}{c}\text { Pre-service } \\
\text { primary school teachers }\end{array}$} \\
\hline & $f$ & $f \%$ & $f$ & $f \%$ & $f$ & $f \%$ \\
\hline \multirow{5}{*}{ fresco paintings } & 0 & 20.0 & 0 & 4.8 & 0 & 15.3 \\
\hline & 1 & 20.0 & 1 & 9.5 & 1 & 8.3 \\
\hline & 2 & 40.0 & 2 & 23.8 & 2 & 34.7 \\
\hline & 3 & 8.0 & 3 & 9.5 & 3 & 20.8 \\
\hline & 4 & 12.0 & 4 & 52.4 & 4 & 20.8 \\
\hline \multirow{5}{*}{$\begin{array}{l}\text { cave paintings } \\
\text { (parietal art) }\end{array}$} & 0 & 8.0 & 0 & 4.8 & 0 & 9.7 \\
\hline & 1 & 36.0 & 1 & 4.8 & 1 & 11.1 \\
\hline & 2 & 36.0 & 2 & 19.0 & 2 & 27.8 \\
\hline & 3 & 4.0 & 3 & 71.4 & 3 & 25.0 \\
\hline & 4 & 16.0 & 4 & 4.8 & 4 & 26.4 \\
\hline \multirow{5}{*}{$\begin{array}{l}\text { paintings on wooden } \\
\text { support } \\
\text { (panel paintings) }\end{array}$} & 0 & 60.0 & 0 & 19.0 & 0 & 37.5 \\
\hline & 1 & 32.0 & 1 & 23.8 & 1 & 33.3 \\
\hline & 2 & 8.0 & 2 & 38.1 & 2 & 19.4 \\
\hline & 3 & 0.0 & 3 & 9.5 & 3 & 5.6 \\
\hline & 4 & 0.0 & 4 & 9.5 & 4 & 4.2 \\
\hline \multirow{5}{*}{ oil paintings on canvas } & 0 & 20.0 & 0 & 4.8 & 0 & 16.7 \\
\hline & 1 & 44.0 & 1 & 14.3 & 1 & 19.4 \\
\hline & 2 & 20.0 & 2 & 19.0 & 2 & 16.7 \\
\hline & 3 & 8.0 & 3 & 33.3 & 3 & 33.3 \\
\hline & 4 & 8.0 & 4 & 28.6 & 4 & 13.9 \\
\hline \multirow{5}{*}{$\begin{array}{l}\text { paintings on paper } \\
\text { (aquarelle) }\end{array}$} & 0 & 24.0 & 0 & 0 & 0 & 5.6 \\
\hline & 1 & 0.0 & 1 & 0 & 1 & 15.3 \\
\hline & 2 & 24.0 & 2 & 33.3 & 2 & 27.8 \\
\hline & 3 & 44.0 & 3 & 23.8 & 3 & 33.3 \\
\hline & 4 & 8.0 & 4 & 42.9 & 4 & 18.1 \\
\hline \multirow{5}{*}{$\begin{array}{l}\text { woven painting } \\
\text { (tapestry) }\end{array}$} & 0 & 36.0 & 0 & 14.3 & 0 & 33.3 \\
\hline & 1 & 32.0 & 1 & 14.3 & 1 & 27.8 \\
\hline & 2 & 20.0 & 2 & 9.5 & 2 & 19.4 \\
\hline & 3 & 8.0 & 3 & 23.8 & 3 & 12.5 \\
\hline & 4 & 4.0 & 4 & 38.1 & 4 & 6.9 \\
\hline
\end{tabular}

It can be summarised from Table 1 that $52.4 \%$ of pre-service fine art teachers correctly answered all four questions in the fresco painting task. Most of the pre-service chemistry teachers $(80 \%)$ correctly answered a maximum of two questions (out of four) about materials that are used in fresco painting. Almost $80 \%$ of pre-service primary school teachers correctly answered a minimum of two questions (out of four) regarding materials of fresco painting. The results of the question regarding fine art materials in cave paintings (parietal art) are similar to those about fresco painting. Most of the pre-service 
fine art teachers (more than $75 \%$ correctly answered three or four questions) recognised materials on cave painting (painting support, type of pigments, and binder). In contrast, almost $80 \%$ of pre-service chemistry teachers answered two questions correctly. Around $80 \%$ of pre-service primary school teachers correctly answered at least two questions (out of four) regarding the materials of which the paintings in caves are made.

The third task, regarding the fine art materials of paintings on a wooden support (panel paintings), was the most demanding for all students. Around $90 \%$ of pre-service chemistry and primary school teachers and more than $60 \%$ of pre-service fine art teachers answered only two or fewer questions correctly. Pre-service teachers' scores on the fourth task (regarding materials of oil paintings on canvas) are similar to the scores that pre-service teachers obtain on the fresco and cave art paintings tasks. Pre-service fine art teachers (around 80\%) and pre-service primary school teachers (about 60\%) achieved better results: more than two correct answers (out of four). Around $80 \%$ of pre-service chemistry teachers correctly answered a maximum of questions. In general, all preservice teachers achieved the highest scores solving the fifth task; understanding materials of paintings on paper (aquarelle). Surprisingly, more than 50\% of all pre-service teachers manage to answer three or four questions correctly, regarding the materials that are used in aquarelle paintings. Almost half of the pre-service fine art teachers (42.9\%) correctly answered all four questions; $44 \%$ of pre-service chemistry teachers correctly answered three questions.

The last task, defining materials in tapestry, was demanding for most pre-service teachers; $31 \%$ of pre-service fine art teachers answered all four questions correctly; most (around 80\%) pre-service chemistry and pre-service primary education teachers correctly answered at most two questions (out of four) regarding materials used in tapestry painting. The results could be compared with findings that experience with the works of fine art could benefit in understanding the chemical characteristics of the materials (Gaquere-Parker \& Perker, 2012; Hemraj-Benny \& Beckford, 2014; Kafetzopoulos, Spyrellis, \& Lymperopoulou-Karaliota, 2006), because the most successful results on the FAMAT were from pre-service fine art teachers followed by pre-service primary school teachers. Both groups of participants had experiences with fine artworks in their undergraduate study. In addition, low FAMAT results among pre-service chemistry teachers confirm that they do not encounter the issues of fine art materials during the study, as can be summarised from the analysis of undergraduate courses for chemistry teachers (https://www.pef.uni-lj.si/204. html); consequently, using interdisciplinary approaches is not possible according to contemporary curriculum guidelines (Devetak, 2017). 
In contrast, pre-service teachers of primary education have less knowledge of fine art materials than pre-service teachers of fine art do, but more than pre-service chemistry teachers do, because they were engaged in chemistry and fine art courses during their undergraduate studies. It can be assumed that preservice primary school teachers are somewhat more interested in science than pre-service fine art teachers and fine art than pre-service chemistry teachers are.

The most challenging task for all pre-service teachers was correctly answering the questions about fine artworks on wooden supports (panel paintings) and tapestry (woven painting). One possible reason that could be identified is the fact that pre-service fine art teachers do not lack experience with the traditional fine art materials and material characteristics. In addition, recognising paper as a fine art material among all pre-service teachers shows that experience with this material helps them understand its characteristics.

The second research question relates to the differences between those pre-service teachers who create fine art products in their free time (drawings, painting, sculpting, etc.) and their counterparts who do not do so on the FAMAT results. An independent-samples t-test was conducted to compare the students' results on FAMAT and their ability to create fine art products in their free time. There was a significant difference in scores between pre-service teachers who create fine art products in their free time $(M=13.1 ; S D=4.52)$ and those students who do not $(M=10.2 ; S D=3.91 ; t(112)=3.61, p \leq .000)$. The magnitude of the differences in the means was very small (eta squared $=.07$ ). These results confirm that experiences with fine art materials help in understanding materials' characteristics during the creation of fine art products.

\section{Pre-service teachers' interest in chemistry and fine art}

The third research question refers to the pre-service chemistry teachers, fine art teachers, and primary school teachers' differences in levels of individual interest and self-concept for learning about fine art material. The ANOVA was conducted to explore the differences between three groups regarding their undergraduate pre-service teacher education programme (Group 1: chemistry, Group 2: fine art, Group 3: primary education) in levels of individual interest and self-concept for learning about fine art materials. The differences in individual interest in learning about fine art materials between participants in different undergraduate programmes are significant $(F(2,115)=24.19, p \leq .000)$. The effect size, calculated using eta squared, was 0.296 ; this means that the effect size is large, and $29.6 \%$ of the change in the individual interest scores can be accounted for by the participants' educational programme at the university. 
Post hoc comparisons using Tukey HSD indicated that the mean score between Group $1(M=12.5 ; S D=3.4)$ was significantly different from Group $2(M=22.1$; $S D=5.1)$ and between Group 1 and $3(M=16.8$; $S D=4.9)(p \leq .000)$. The difference between Group 2 and Group 3 is also statistically significant $(p \leq .000)$. The differences in self-concept for learning about fine art materials between participants in different undergraduate programmes are significant $(F(2,115)=$ $9.56, p \leq .000$ ). The effect size, calculated using eta squared, was .14; this means that the effect size is large, and $14 \%$ of the change in self-concept scores can be accounted for by the students' educational programme. Post hoc comparisons using Tukey HSD indicated that the mean score between Group $1(M=5.7 ; S D$ = 2.2) was significantly different from Group $2(M=9.0 ; S D=2.9)(p \leq .000)$, and between Group 1 and $3(M=7.3 ; S D=2.6)(p=.020)$ and between Groups 2 and $3(p=.024)$. More detailed results about pre-service teachers' individual interest and self-concept are presented in Table 2.

Table 2

Results of individual interest questionnaire (IIQ)

\begin{tabular}{|c|c|c|c|c|c|c|}
\hline \multirow[t]{2}{*}{$\begin{array}{l}\text { Items defining individual interest in learning } \\
\text { about fine art materials. }\end{array}$} & \multicolumn{2}{|c|}{$\begin{array}{l}\text { Pre-service } \\
\text { chemistry } \\
\text { teachers }\end{array}$} & \multicolumn{2}{|c|}{$\begin{array}{l}\text { Pre-service } \\
\text { fine art teachers }\end{array}$} & \multicolumn{2}{|c|}{$\begin{array}{l}\text { Pre-service } \\
\text { primary school } \\
\text { teachers }\end{array}$} \\
\hline & $M$ & $S D$ & $M$ & $S D$ & $M$ & $S D$ \\
\hline $\begin{array}{l}\text { I am interested in works of fine art, so I am } \\
\text { often viewing them (in galleries, churches, etc.). }\end{array}$ & 2.33 & 1.12 & 3.57 & .74 & 2.48 & .85 \\
\hline $\begin{array}{l}\text { I want to deepen my understanding of prob- } \\
\text { lems related to the fine art materials. }\end{array}$ & 1.12 & .33 & 2.28 & 1.05 & 1.72 & .79 \\
\hline $\begin{array}{l}\text { I am focused when I have the opportunity to } \\
\text { get to know the contents of fine art materials. }\end{array}$ & 1.40 & .64 & 2.47 & 1.36 & 1.79 & 1.07 \\
\hline $\begin{array}{l}\text { I put more effort into learning about fine art } \\
\text { materials than required by my study. }\end{array}$ & 1.20 & .50 & 2.19 & 1.12 & 1.69 & .91 \\
\hline I like experimenting with fine art materials. & 1.76 & 1.20 & 3.42 & .59 & 2.33 & 1.13 \\
\hline $\begin{array}{l}\text { While I am observing artworks (paintings, } \\
\text { sculptures, etc.) I wonder about what kind of } \\
\text { materials they are made of. }\end{array}$ & 1.20 & .70 & 2.85 & .96 & 2.06 & .90 \\
\hline $\begin{array}{l}\text { I am interested in learning about fine art materi- } \\
\text { als, also in my free time. }\end{array}$ & 1.16 & .68 & 1.90 & 1.04 & 1.44 & .70 \\
\hline $\begin{array}{l}\text { Everything related to fine art materials attracts } \\
\text { my attention. }\end{array}$ & 1.28 & .73 & 1.85 & 1.10 & 1.59 & .92 \\
\hline $\begin{array}{l}\text { When I want to figure out which of the ma- } \\
\text { terials the artwork is made of, I persist until I } \\
\text { understand it. }\end{array}$ & 1.12 & .33 & 1.57 & .97 & 1.66 & .76 \\
\hline
\end{tabular}




\begin{tabular}{|c|c|c|c|c|c|c|}
\hline \multirow[t]{2}{*}{$\begin{array}{l}\text { Items defining self-concept for learning about } \\
\text { fine art materials. }\end{array}$} & \multicolumn{2}{|c|}{$\begin{array}{l}\text { Pre-service } \\
\text { chemistry } \\
\text { teachers }\end{array}$} & \multicolumn{2}{|c|}{$\begin{array}{l}\text { Pre-service fine } \\
\text { art teachers }\end{array}$} & \multicolumn{2}{|c|}{$\begin{array}{l}\text { Pre-service } \\
\text { primary school } \\
\text { teachers }\end{array}$} \\
\hline & M & $S D$ & $M$ & $S D$ & M & $S D$ \\
\hline $\begin{array}{l}\text { The content dealing with the materials of fine } \\
\text { art products is not too difficult to understand. }\end{array}$ & 1.40 & .91 & 1.95 & 1.02 & 1.75 & .83 \\
\hline $\begin{array}{l}\text { When I create artwork with different materials } \\
\text { (for example, painting, sculpturing, making } \\
\text { posters, etc.) I achieve good grades. }\end{array}$ & 1.80 & 1.19 & 3.00 & 1.37 & 2.25 & 1.29 \\
\hline $\begin{array}{l}\text { I am a quick learner regarding the contents of } \\
\text { fine art materials. }\end{array}$ & 1.28 & .73 & 2.61 & 1.11 & 1.87 & 1.14 \\
\hline I am good at recognising fine art materials. & 1.20 & .50 & 1.42 & 1.24 & 1.43 & .76 \\
\hline
\end{tabular}

The highest, but still moderate, on a five-point scale, individual interest in general for learning about fine art materials was reported by pre-service fine art teachers $(M=2.5 ; S D=1,0)$. Pre-service chemistry teachers expressed very low individual interest in this topic $(M=1.4 ; S D=.7)$, but pre-service primary school teachers showed slightly higher individual interest $(M=1.9 ; S D=.9)$ than their chemistry counterparts did. This is understandable, because they will teach fine art and science to students aged from 6 to 11 years.

It can also be summarised from Table 2 that the lowest level of expressed individual interest in fine art materials was identified among pre-service chemistry teachers; they do not put much effort into learning more than their studies require $(M=1.2 ; S D=.5)$; when observing artworks (paintings, sculptures, etc.), they do not wonder about what kind of materials they are made of ( $M=$ 1.2; $S D=.7)$, and they do not insist on finding out what materials are used in the specific artwork $(M=1.1 ; S D=.3)$.

In contrast, pre-service primary school teachers have higher levels of individual interest regarding learning about fine art materials in comparison with pre-service chemistry teachers. In general, they lack competences for recognising fine art materials and have low individual interest in learning about them in their free time. Taking into account pre-service teachers' self-concept about learning about fine art materials it is obvious that fine art teachers expressed the highest level of self-concept for this topic $(M=2.2 ; S D=1.2)$, followed by primary school teachers $(M=1.8 ; S D=1.0)$, and then by pre-service chemistry teachers $(M=1.4$; $S D=.8$ ). It can be concluded from Table 2 that pre-service fine art teachers have the highest self-concept regarding learning about fine art materials through fine art experience $(M=3.0 ; S D=1.4)$. This was expected. Regardless, in general, they lack a self-concept regarding recognising (defining) the materials of artworks in general $(M=1.4 ; S D=1.2)$. Compared to the others, pre-service fine art teachers have much more knowledge but, in general, the level is low, which is also reflected 
in their self-esteem; they are not completely overwhelmed by properly defining fine art materials, which were presented in the research. We can review some of their comments regarding the research problem: pre-service fine art teachers would like to understand which materials are compatible, how and why some materials react under certain conditions, from what they are composed, how to obtain some materials, how to use materials at school, etc. Some excluded any kind of dealing with the chemical compositions of materials during their study process or simply lacked awareness that fine art materials are something more than just products to be bought in a shop.

For the fourth research question, ANOVA was conducted to explore the differences between the three groups of participants that expressed different levels of individual interest (Group 1: low, Group 2: average, Group 3: high individual interest) in fine art material regarding their achievement score on FAMAT. The differences are statistically significant $(F(2,115)=9.53 p \leq .000)$. The effect size, calculated using eta squared, was o.14; this means that effect size is large and $14 \%$ of the change in the FAMAT score can be accounted for by the students' higher individual interest in fine art material. Post hoc comparisons using Tukey HSD indicated that the mean score between Group $1(M=9.6 ; S D$ $=3.4)$ and Group $3(M=15.2 ; S D=4.9)$ is significant $(p \leq .000)$. The difference between Group $2(M=11.7 ; S D=4.2)$ and Group 3 is also significant $(p=.003)$. There is no significant difference between those pre-service teachers who express low and average interest in fine art materials. According to these results, it can be confirmed that higher levels of situational interest and self-concepts in learning about fine art materials results in better understanding of this topic as well as to the higher intrinsic motivation for learning more complex content.

The fifth research question deals with the pre-service teachers' self-concept for art materials and their achievements with FAMAT. The ANOVA was conducted to explore the differences between three groups (Group 1: low self-concept, Group 2: moderate self-concepts, Group 3: high self-concept in fine art material) regarding their achievement score on FAMAT. The differences are not statistically significant $(F(2,115)=2.42 ; p=.094)$ between Group $1(M=10.4 ; S D=4.6)$, Group $2(M=12.0$; $S D=4.3)$ and Group $3(M=13.8 ; S D=4.8)$. According to these results, participants' awareness of their learning problems about fine art materials does not influence the achievements that participants demonstrate in solving knowledge tasks about recognising fine art materials in artworks and what their chemical composition is. 


\section{Conclusions}

The basic research problem of this study was to determine the level of knowledge of pre-service teachers from different university educational programmes about fine art materials using a four-tier test and how this knowledge is connected with the level of their individual interest and self-concept for learning about fine art materials. It can be concluded that pre-service teachers' scores on the fine art materials achievement test (FAMAT) are not sufficient (average score is below 49.6\%) and that more emphasis should be placed on developing the understanding of chemistry and fine art concepts due to the fact that fine art and chemistry can be interdisciplinarily connected in education, according to contemporary curriculum guidelines. This is important for all preservice teacher programmes that were selected for this study, especially because all teachers should be generally educated. For that matter, chemistry teachers (they already have professional competences to teach chemistry) should be familiar with specific materials and fine art techniques used in different periods of history. In contrast, fine art teachers ought to understand the specific chemical characteristics of substances used for fine art products in their professional career as a teacher. However, primary school teachers need to be competent in teaching science and fine art classes and, for that reason, they should learn both expect from the discussed problem. It was expected that better results would be achieved by pre-service fine art teachers, because of their experience with fine art material. In contrast, pre-service chemistry teachers show the least knowledge in fine art materials, because of their lack of experience with such material in general as well as lack of awareness of the materials of which artworks are made.

However, the results also reveal that pre-service primary school teachers' knowledge of fine art material is somewhat lower than that of fine art teachers but better than that of chemistry teachers. This is a consequence of the fact that they have some experiences with fine art materials during their studies, which results in better understanding. The results also confirmed that those pre-service teachers who create fine art products in their free time (e.g., drawings, painting, sculptures) express higher knowledge of fine art materials.

It can also be summarised from the results that individual interest and self-concept for learning about fine art materials differ according to the study programme at the university and that these two variables also influence knowledge about fine art materials that was measured by the FAMAT. Works of fine art could be a great tool for interdisciplinary approaches to teaching the contents of chemistry and fine art, so cooperation between teachers is necessary. 
For cooperation between different teacher profiles, knowledge about fine art materials from the chemistry perspective is necessary, as is designing learning units to help with already developed teaching approaches in fine art, science, and chemistry classes. Good practices can already be found, for example, on the web page of the Royal Society of Chemistry, under the title 'Chemistry and Art', accessible at http://www.rsc.org/learn-chemistry/resources/art/home.

It could also be recommended that chemistry teachers use the context of fine art materials to teach the chemical characteristics of substances. Those primary and secondary school students who are not intrinsically motivated to learn chemistry but show more interest in fine art activities could benefit more from chemistry classes. However, this aspect could be expressed vice versa by emphasising that integrating chemistry expects in fine art classes could stimulate those students who are not interested in fine art activities. The low level of pre-service teachers knowledge about fine art materials suggest that an interdisciplinary elective course (e.g., topics regarding inorganic pigments and organic dyes as painting material, polar and non-polar solvents for dissolving pigments and dyes, chemical characteristics of cellulose and limestone as painting supports, plastics and clays as polymers for sculpturing, etc.) in pre-service teacher education programmes at the university level should be developed for building competences for integrating chemistry into fine art classes and vice versa.

\section{Limitations of this study}

The most obvious limitation of this paper is that there are very few reports about students' knowledge and interest in fine art material. As mentioned above, numerous papers have been published especially about introducing specific art actives that can be implemented into the science (chemistry) classroom. The other limitation is also the small sample size (due to the lower numbers fine art and chemistry students enrolled in master level education). It would be prudent to repeat the data collection process in the coming academic years so that the number of students would increase. However, specific insights to the problem presented in this paper could be given, even though the sample size is small.

\section{Further research}

According to the results of this study and also taking into account the literature already published internationally, more research should be conducted to explore: (1) the differences in knowledge about fine art materials among fine art pre-service and in-service teachers regarding their level of undergraduate 
and master education; (2) how to develop and evaluate courses of fine art materials for fine art, chemistry, and primary school pre-service teachers; (3) more detailed analysis should be conducted regarding students' misconceptions about fine art materials; (4) in-service fine art, chemistry, and primary school teachers' interdisciplinary approaches to teaching fine art, chemistry, and science should be explored.

\section{References}

Alves, H. Manhita, A., Barrocas Diasb, C., \& Ferreira, T. (2014). Traditional dyeing - an educational approach. Chemistry Education Research and Practice, 15(4), 610-619.

Belova, N., \& Eilks, I. (2014). Promoting societal-oriented communication and decision making skills by learning about advertising in science education. Center for Educational Policy Studies Journal, 4(1), 31-49.

Brown, H. B., Losoff, B., \& Hollis, R. D. (2014). Science instruction through the visual arts in special collections. Libraries and the Academy, 14(2), 197-216.

Burton, J., Horowitz, R., \& Abeles, H. (1999). Learning in and through the arts: Curriculum implication. In E. B. Fiske (Ed), Champion of change: The impact of the arts on learning (pp. 35-46). Columbia, NY: Columbia University.

Caleon, I., \& Subramaniam, R. (2010). Development and application of a three-tier diagnostic test to assess secondary students' understanding of waves. International Journal of Science Education, 32(7), $939-961$.

Denio, A. A. (1979). Chemistry for artists and art buffs, chemistry for artists and art buffs. Journal of Chemical Education, 56(1), 30-33.

Denio, A. A. (2001). The joy of colour in ceramic glazes with the help of redox chemistry. Journal of Chemical Education, $78(10), 1298$.

Danipog, L. D., \& Ferido, B. M. (2011). Using art-based chemistry activities to improve students' conceptual understanding in chemistry. Journal of Chemical Education, 88(12), 1610-1615.

Devetak, I. (2017). Context-based teaching material and learning chemistry. In L. Leite, L. Dourado, A. S. Afonso, \& S. Morgado (Eds.), Contextualizing teaching to improve learning: the case of science and geography (pp. 261-282). New York, NY: Nova science.

Dhanapal, S., Ravi Kanapathy, R., \& Mastan, J. (2014). A study to understand the role of visual arts in the teaching and learning of science. Asia-Pacific Forum on Science Learning and Teaching, 15(2), 1-25. Epp, N. D. (1995). World of colour: Investigating the chemistry of vat dyes. Journal of Chemical Education, 72(8), 726-727.

Gaquere-Parker, A. C., Allie Doles, N., \& Parker, C. D. (2016). Chemistry and art in a bag: An easy-toimplement outreach activity making and painting with a copper-based pigment. Journal of Chemical Education, 93(1), 152-153.

Gaquere-Parker, A. C., \& Parker, C. D. (2012). Bridging the gap of art and chemistry at the introductory level. In P. L. Lang, \& R. A. Armitage (Eds.), Collaborative endeavors in the chemical analysis of art and cultural heritage materials (pp. 241-249). Washington, DC: American Chemical Society. 
Gimenez, J. (2015). Finding hidden chemistry in ancient Egyptian artefacts: Pigments degradation taught in a chemical engineering course. Journal of Chemical Education, 92(3), 456-462.

Gurel, K. D., Eryilmaz, A., \& McDermott, C. L. (2015). A review and comparison of diagnostic instruments to identify students' misconceptions in science. EURASIA Journal of Mathematics, Science and Technology Education, 11(5), 989-1008.

Hemraj-Benny, T., \& Beckford, I. (2014). Cooperative and inquiry-based learning utilizing art-related topics: Teaching chemistry to community college non-science majors. Journal of Chemical Education, 91(10), 1618-1622.

Hidi, S. (2000). An interest researcher's perspective: The effects of extrinsic and intrinsic factors on motivation. In C. Sansone, \& J. M. Harackiewicz (Eds.), Intrinsic and extrinsic motivation: The search for optimal motivation and performance (pp. 309-339). San Diego, CA: Academic Press.

Juriševič, M., Devetak, I., Razdevšek-Pučko, C., \& Glažar, S. A. (2008). Intrinsic motivation of preservice primary school teachers for learning chemistry in relation to their academic achievement. International Journal of Science Education, 30(1), 87-107.

Kafetzopoulos, C., Spyrellis, N., \& Lymperopoulou-Karaliota, A. (2006). The chemistry of art and the art of chemistry. Journal of Chemical Education, 83(10), 1484-1488.

Kolb, E. K., \& Kolb, K. D. (2000). Glass-sand + imagination. Journal of Chemical Education, 77(7), 812-816.

Landsman, T. (1962). The role of the self-concept in learning situations. The High School Journal, 45(7), 289-295.

McCarthy, P., \& Schmeck, R. R. (1988). Students's self-concepts and the quality of learning in public schools and universities. In R. R. Schmeck (Ed.), Learning strategies and learning styles (pp. 263-276). New York, NY: Springer.

Newman, J. A. (1972). The arts and the sciences: A very miscible solution. Science Education, 56(2), 137-138.

Orna, V. M. (2001). Chemistry, colour, and art. Journal of Chemical Education, 78(10), 1305-1310.

Potočnik, R. (2017). Effective approaches to heritage education: Raising awareness through fine art practice. International Journal of Education through Art, 13(3), 285-294.

Pressley, M., El-Dinary, P. B., Marks, M. B., Brown, R., \& Stein, S. (1992). Good strategy instruction is motivating and interesting. In A. Renninger, S. Hidi, \& A. Krapp (Eds.), The role of interest in learning and development (pp. 333-357). Erlbaum: Hillsdale.

Renninger, K. A. (2000). Individual interest and its implications for understanding intrinsic motivation. In C. Sansone, \& J. M. Harackiewicz (Eds.), Intrinsic and extrinsic motivation: The search for optimal motivation and performance (pp. 373-40o). San Diego, CA: Academic Press.

Schraw, G., Flowerday, T., \& Lehman, S. (2001). Increasing situational interest in the classroom. Educational Psychology Review, 13(3), 211-224.

Slapničar, M., Devetak, I., Glažar, S. A., \& Pavlin, J. (2017). Identification of the understanding of the states of matter of water and air among Slovenian students aged 12, 14, and 16 years through salving authentic tasks. Journal of Baltic Science Education, 16(3), 308-323. 
Solomon, D. S., Rutkowsky, S. A., Mahon, L. M., \& Halpern, M. E. (2011). Synthesis of copper pigments, malachite and verdigris: Making Tempera paint. Journal of Chemical Education, 88(12), 1694-1697. Stamovlasis, D. (2003). Teaching photography: Interplay between chemical kinetics and visual art. Chemistry Education Research and Practice, 4(1), 55-66.

Treagust, D. F. (1988). Development and use of diagnostic tests to evaluate students' misconceptions in science. International Journal of Science Education, 10(2), 159-170.

Uffelman, E. S. (2007). Teaching science in art: Technical examination of 17th-century Dutch painting as interdisciplinary coursework for science majors and non-majors. Journal of Chemical Education, $84(10), 1617-1624$.

Vrtačnik, M. (2004). Chemistry in art and art in chemistry. In D. Krnel, \& S. A. Glažar. (Eds.), Programme and abstracts, 7 th ECRICE, European Conference on Research in Chemical Education [and] 3rd ECCE, European conference on chemical education (pp. 22-23). Ljubljana: Zavod Republike Slovenije za šolstvo.

Wells, G., \& Haaf, M. (2013). Investigating art objects through collaborative student research projects in an undergraduate chemistry and art course. Journal of Chemical Education, 9o(12), 1616-1621.

\section{Biographical note}

Ropert Potočnik, PhD, is an Assistant Professor of Fine Art Education and holds a degree in fine arts conservation - restauration and fine arts education. His research interests are in the didactics of fine art education, preservation education and cultural heritage conservation.

Iztok Devetak, PhD, is an Associate Professor of Chemical Education at University of Ljubljana, Faculty of Education, Slovenia. His research focuses on students' chemistry learning and their motivation, how chemistry in context stimulates learning, using eye-tracking technology in explaining science learning, aspects of environmental education, and the development of teachers' health-managing competences. 